To prove the point and to prepare the way for clinical trials, Endorphin Inc. now needs a quantity of pancreatic endorphin that would be difficult to purify from pig pancreas but should be well within the production capacity of bacteria into which the relevant gene has been cloned.

The choice of University College for this task seems in large part to have been based on the fact that Professor Houck has been a visiting fellow there for several years. It may also have been cheaper to contract for the work in the United Kingdom than in the United States. But for the department of biochemistry, whose annual support from the university for overheads has been cut from $£ 80,000$ to $£ 60,000$ (an even more drastic cut in real terms), the contract allows at least one project to be carried out

\section{Europe leads on sequences}

Europe appears, for a change, to have beaten the United States to the mark. The European Molecular Biology Laboratory (EMBL) at Heidelberg has announced the formation of a nucleotide sequence library, while the National Institutes of Health (NIH) in Washington are still deliberating the question.

Not that there is any sense of competition. Greg Hamm, manager of the Heidelberg library, is "still talking" to $\mathrm{NIH}$, and wishes to cooperate with any system that NIH may set up. But EMBL was under pressure from European scientists to start now, before sequence data were irretrievably lost. EMBL is not attempting to become the sole manager of world sequence data, Hamm insists.

The question now is how to collect the data efficiently. The 600,000 nucleotides already logged at Heidelberg (they are freely available on magnetic tape) have taken an immense effort to collect. This is largely because journals do not use the clearest of systems for displaying the sequences, say Hamm and Professor Ken Murray in a letter recently sent to journal editors.

Hamm and Murray are recommending that journals should insist on the separate

submission of sequence data to the EMBL library, preferably in a format specified by EMBL, and if possible in computerreadable form. Some of these requirements, however, conflict with common format in journals. For example, codons should be presented in tens or fifteens of nucleotides rather than the triplets which correspond to the translation of the code into amino acids, says EMBL, to reduce counting errors; and the marking of reading frames and alignment of comparable sequences should be avoided.

According to Hamm, however, such requirements are only important for the easy transferral of the data into the EMBL computer: the printed format in a journal, which is intended to present the data heuristically, emphasizing the significance of regions of a sequence, could be quite different - provided EMBL were sent the uncluttered sequence according to their own guidelines.

So far, only the Journal of Molecular Biology, edited by Sir John Kendrew, has said it will implement the EMBL proposals in full. Nucleic Acids Research is said to be "basically positive", but discussing details. Nature is considering the matter.

Robert Walgate

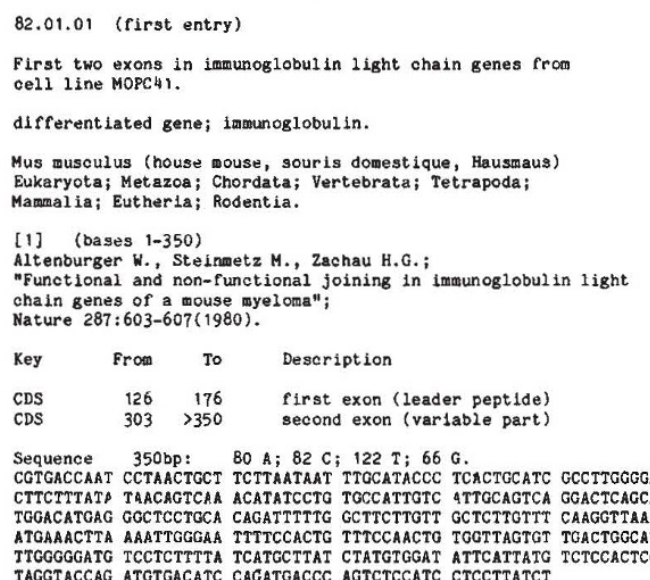

Polish universities

\section{Trial by proxy}

\section{New York}

The International Council for the Future of the University (ICFU), a New York based organization of some 300 academics from 21 countries, committed to the defence of Western university traditions, has launched a study of the current situation in Polish universities. This marks a major change in ICFU policy. Previous studies have dealt with Western European countries (Sweden, Italy, West Germany) to which it was possible to send working parties and in which the ICFU already possessed members who could contribute first-hand knowledge of recent events. But with no Polish members of ICFU, and with the continuation of martial law the possibility of an ICFU commission visiting Poland in the near future seems remote.

The inaugural meeting for the new study, which was held in New York earlier this month, had to do the best it could with the testimonies of visitors, including Andrzej Kaminski, a mediaeval historian who left Poland before the foundation of Solidarity, two representatives of the banned Independent Students' Union (NZS) and Wojciech Karpinski, a political scientist and former activist now at Yale. Inevitably, their accounts of Polish university history did not cover the period of martial law. The most up-to-date material, including the martial law regulations governing the universities (see Nature 31 January, p.181), came from the floor. A detailed discussion of the events which followed the military take-over was deferred to a meeting to be held in Paris later this year.

More incongruously, the reforms urged and in part initiated in Polish universities during the 16 months of "renewal" (between 30 August 1980 and 12 December 1981), had been largely directed towards greater democracy ranging from student representation on the academic councils of universities to the possible election of a Minister of Higher Education by the university rectors - a proposal put forward only a few days before the imposition of martial law, and one which was later described by Deputy Prime Minister Mieczyslaw Rakowski as "the academics running amok". This trend contrasts sharply with the attitude of ICFU, which has tended to see too much democracy as a potential threat. But this divergence of views may make it easier for the Polish authorities to accept the impartiality of the proposed ICFU study. If the Polish propagandists look at the track record of ICFU it might find it difficult to make out a plausible case that ICFU is manipulated by Solidarity extremists abroad, when for the past ten years it has systematically deplored many of the reforms since advocated by Solidarity.

Vera Rich 